\title{
Confiscation for Heresy in the Middle Ages
}

TN many ways which have attracted little attention, the Inquisi1 tion was a factor of importance in the development of the middle ages. Under the theocracy which was the social ideal of Latin christianity, the enforcement of aniformity of faith was the bighest duty of both chorch and state. To accomplish this the dongeon and the stake were not spared, but an equally efficacious instrument was the forfeiture of the heretic's property.

For the source of this pensity, as of so much else, we must look to the Roman law. It is true that, cruel as were the imperial edicts against heresy, they did not go to the length of thus indirectly punishing the innocent. Even when the detested Manicheans were mercilessly condemned to desth, their property wes confiscated only when their heirs were likewise heretics. If the children were orthodox, they succeeded to the estate of the heretic parent, who could not erecate a will and disinherit them. It was otherwise with crime. Any conviction involving deportation or the mines carried with it confiscation, though the wife could reclaim her dower and any gifts made to her before the commission of the offence, and so could children emsncipated from the patria potestas. In majestas, or treason, the offender was lisble to condemnation after death, involving the confiscation of his estate, which was held to have lapsed to the fisc at the time when he first conceived the crime. These provisions furnished the armoury whence pope and king drew the weapons which rendered the pursuit of herest attractive and profitable. ${ }^{3}$

King Roger, who occupied the throne of Naples during the first half of the twelfth century, seems to have been the first to apply the Boman practice by decreeing confiscation for all who apostatised from the catholic faith-whether to the Greek church, to Islam, or to Jodsism, does not appear. Yet the church cannot escape the responsibility of naturalising this penalty in European law as a punishment for spiritual transgressions. The great council of Tours, held by Alezander III in 1168, commanded all

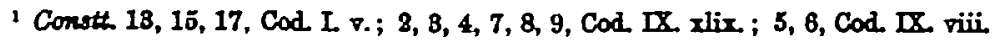


secular princes to imprison beretics and confiscate their property. The Verona decretal of Lucius III in 1184 songht to obtain for the church the benefit of the confiscation, which he declared was incurred by heresy. One of the earliest ants of Innocent III, in his double capacity of temporal prince and head of christianity, was to address a decretal to his subjects of Viterbo, in which he says:

In the lands subject to our temporal jurisdiction we order the property of heretics to be confiscated ; in other lands we commend this to be done by the temporal princes and powers, who, if they show themselves negligent therein, shall bo compelled to it by ecclesiastical censures. Nor shall the property of heretics who withdram from heresy revert to them, unless some one pleases to take pity on them. For as, according to the legal sanctions, in addition to capital punishment, the property of those guilty of majestas is confiscated, and life simply is allowed to their children through mercy alone, so much the more ahould those who wander from the faith and offend the Son of God be cat off from Christ and be despoiled of their temporal goods, since it is a far greater crime to assail spiritual than temporal majesty."

This decretal, which was adopted into the canon lsw, is important as embodying the whole theory of the subject. In imitation of the Roman lar of majestas, the property of the heretic was forfeited from the moment he became a heretic or committed an act of heresy. If he recanted, it might be restored to him parely in mercy. When the ecclesiastical tribunals declared him to be, or to have been, a heretic, confiscation followed; the act of seizing the property and the mercy which might spare it were matters for the secular power.

Innocent III's decretal further illustrates the fact that, at the commencement of the struggle with heresy, the chief difficalty encountered by the church in relation to confiscation was to persuade or coerce the temporal rolers to do their daty in taking possession of heretical property. This was one of the principal offences which Raymond VI of Toulouse expiated so bitterly, as Innocent explained to him in 1210. His son proclaimed confiscation as the law in his statutes of 1284 , and included in its provisions, in accordance with the ordonnance of Lonis VIII in 1226 and that of Louis IX in 1229, all who favoured heretics in any way or refused to aid in their capture; but, as his policy did not always agree with its enforcement, he sometimes had to be sternly rebuked for neglect. After all danger of armed resistance had disappeared, sovereigns as a rule eagerly welcomed the opportunity of recruiting

t Constt. Sicular. lib. i. tit. 3. Concil Taronens ann. 1163, c. 4. Lacii PP. III epist 171. Innoc. PP. III regest ii. 1. Cap. 10 Extra. v. 7. It was probsbly in obedience to the canon of Tours that in 1178 the property of Pierre Msoran of Toulouse was declared forfeited to the connt, end he was allowed to redeem it rith a fine of five handred poonds of silver. Roger Hoveden. Annal ann. 1178. 
their slender revenues; the confiscation of the property of heretics and of fautors of heresy was generally recognised in European law, although the church was occasionslly obliged to repeat its injunctions and threats, and although there were some regions in which they were slackly obeyed. ${ }^{3}$

The relation of the ecclesiastical conrts to confiscation varied essentially with time and place. In France the principle derived from the Roman law was generally recognised, that the title to property devolved to the fisc as soon as the crime had been committed. There was therefore nothing for the inquisitor to do with regard to it. He simply ascertained and announced the guilt of the accused, and left the state to take action. Thus Gui Foacoir treats the subject as one wholly outside of the functions of the inquisitor, who at most can only adrise the secular ruler, or intercede for mercy; while he holds that those only are legally exempt from forfeiture who come forward spontaneously and confess before any evidence has been taken against them. In accordance with this, there is, as a rale, no allusion to confiscation in the sentences of the French Inquisition; though in one or two instances chance has preserved for us, in the accounts of the procureurs des encours, or royal stewards of the confiscations, evidence that estates were sold in behalf of the fise in cases in which the forfeiture is not specified in the sentence. In condemnations of absentees and of the dead, confiscation is occasionally declared, as though in these the state might need some guidance; bat even here the practice is not uniform. In the register of Bernard de Canx (1246-1248), in thirtytwo cases of contumacious absentees, confiscation is included in the sentence, and in nine similar ones it is omitted, as well as in 159 condemastions to prison, in which it was undoubtedly operative. In the Inquisition of Carcassonne, a sentence of 12 Dec. 1328 on five deceased persons, who would have been imprisoned had they

3 Innoc. PP. III regest. xï. 154 (cep. 26 Extre v. xl) Isembert, Ame. Loir Franç. i. 228, 232. Herduin vii 203-8. Veissetto, Hist. G(m de Langrudoc, iii. pr. 385 . Concil Albiens. ann. 1354 0. 26. Innoc. PP. IV bolle Cum fratres, ann 1252 (Mrag. Bull Bom i. 90). Confiscation pas an ordinary resource of modieval lam. In Englend, from the time of Atred, property as well es life was forteited for treason (Altred's Dooms, 4; Thorpe, i. 63), a penalty which was retained ontil 1870 (Low and Palling's Dictionary of Einglish History, p. 469). In France, marder, talse vituess, treachory, homicide, and repe were all punishod with death snd confiscation (Beanmenoir, Coutumas du Beaveoiris, Irx. 2-5). By tho German fendal lar the fiet might be forfeitod for a rast number of offences, but the distinction vas drawn thet if the offence was sqainst the lord the flet reverted to him, if for simply a arime it descended to the heirs (Feudor. lib. i. tit. zxiii-iv.) In Navarre, confliscation formed part of the penalties of suicide, murder, treason, and even of blows or wounds inflictod where the queen or royel children were $d$ welling. There is a case in which conflscetion was entorced on a man because bo struck another at Olite, which was within a league of Tatalle, where the queen chenced to be steying at the time (G. B. de Lagritze, Lo Navarre Frangaise, ij. 335). 
lived, ends with et consequenter bona ipsorum dicimus confiscanda, while a previous sentence, 24 Feb. 1325, identical in character, on four defunct culprits, has no such corollary appended. In fact, strictly speaking, it was recognised that the inquisitor had no power to remit confiscations without permission from the fisc, and the custom of extending mercy to those who came forward voluntarily and confessed was founded upon a special concession to that effect, granted by Raymond of Toulonse to the Inquisition in 1285. As soon as a suspected heretic was cited or arrested, the secular officials sequestrated his property and notified his debtors by proclamation. No doubt when condemnation took place, the inquisitor communicated the result to the proper officials; but, as a rule, no record of the fact soems to have been kept in the archives of the holy office, although an early manual of practice specifies it as part of his duty to see that the confiscation was enforced. ${ }^{4}$

In Italy it was long before any settled practice was established. In 1252 a bull of Innocent IV directs the ralers of Lombardy, Tarvisina, and Romagns to confiscate without fail the property of all who are excommunicated as heretics, or as receivers, defenders, or fautors of heretics, thus recognising confiscation as a matter bolonging to the secular power. Yet soon the papal anthority succeeded in obtaining a share of the spoils, even beyond the limits of the states of the church, as is seen in the balls ad extirpanda of Innocent $I V$ and Alexander $T$, and the matter thus became one in which the Inquisition had a direct interest. The indifference which so well became the French tribunals was therefore not readily maintained, and the share of the inquisitor in the results led him to participate in the process of securing them. Yet there were variations in practice. Zanghino Jgolini tells us that formerly confiscations were decreed in the States of the Charch by the ecclesiastical judges, and elsewhere by the secular power, bat that in his time (circa 1320) they were everywhere in Italy included in the jurisdiction of the episcopal and inquisitorial courts, and the secular authorities had nothing to do with them; bat he adds that confiscation is prescribed by law for heresy, and that the inquisitor has no discretion to remit it, except in the case of voluntary converts with the essent of the bishop. Yet, though the forfeiture occurs ipso facto by the commission of the crime, it requires a declarstory sentence of confiscation. This consequently was expressed in the most formal manner in the condemnation of the accused by the Italian Inquisition, and the secular authorities were ordered not to interfere unless called upon."

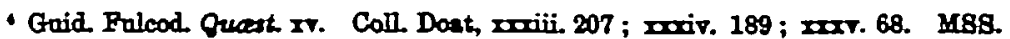
Bib. Nat fonde latin, No. 9992 Coll. Doet, xnviii. 131, 164. Responea Pruderterm (Doat, novii. 83). Grasdes Chroniques, ann. 1389. Les Olim, ti p. 656. Grill. Pelisso, Chrom, ed. Moliniar, p. 27. MS8. Bih Net fands letin, Na. 14930, tol 224.

s Coll Dost, xrri. 175. Zsnehini Tract. de Haret. a Iviii Irv. xrvi sli. 
At a very early period in some places the Italian inquisitors seem to have undertaken not only to decree but to control the confiscations. About 1245 we find the Florentine inquisitor, Ruggieri Calcagni, sentencing a relspsed Catharan to a fine of one hundred lire. Ruggieri acknowledges the receipt of this, to be applied to the pope or to the furtherance of the faith, and formally concedes the rest of the heretic's estate to his wife, thus exercising ownership over the whole. Yet this was not maintained, for in 1283 there is a sentence of the podestà of Florence reciting that the inquisitor Fra Salomone da Lucea had notified him that the widow Ruvinosa, lately deceased, had died a heretic and that her property was to be confiscated; wherefore he orders it to be seized and sold, and the proceeds divided according to the papal constitutions. At length, however, the inquisitors assumed and exercised full control over the handling of the confiscations. In the conveyance of a confiscated house by the municipal authorities of Florence in 1327 to the Dominicans, the deed is careful to assert that it is made with the assent of the inquisitor. Even in Naples we see King Robert in 1324 ordering the inquisitors to pay out of the royal share of the confiscations fifty onces of gold to the prior of the church of San Domenico of Naples to aid in its completion. ${ }^{\circ}$

In Germany the diet of Worms in 1231 indicates the confusion eristing in the feudal mind between heresy and tresson by allowing the allodial lands and personal property of the condemned to descend to the heirs, while fiefs were confiscated to the seignior. If the colprit was a serf, his goods enured to his master; but from all personal property was deducted the cost of burning its owner and the droits de justice of the seignour justicior. Two years later, in 1298, the council of Mainz protested against the injustice, which quickly showed itself in Germany as elsewhere, of assoming guilt as soon as a man was accused, and treating his property as though he were convicted. It directed that the estates of those on trial should remain untouched until sentence was rendered, and any one who meanwhile should plunder or partition them should be excommanicated antil he made restitution and rendered satisfaction. Finslly, when the Emperor Charles $I V$ endearoured to introduce the Inquisition into Germany in 1969, he adopted the Italian cnstom and ordered one-third of the confiscations to be made over to the inquisitors.?

The exact degree of criminality which entailed confiscation is

- Lemi, Antichitd Toseane, pp. 560, 588-9. Zapehini Tract de Haret. a Ixvi. Arahivio di Firense, Prov. A. Maria Novalle, 18 Nov. 1397. Arehivio di Nepoli, regist. 253 lett. A, fol. 68.

" Fint Diplom Frid. II, t. iii. p. 166. Kaltner, Bonrad 0. Marburg us die Inquisition, Prag, 1882, p. 147. Moshoim de Beghardis, p. 347. 
not capable of very rigid definition. Even in states where the inquisitor nominally had no control over it, his arbitrary discretion as to the fate of the accused placed the matter practically in his hands, and his notification to the secular anthorities would be a virtual sentence. It is probable that custom varied with time and with the temper of the inquisitor. We hsve seen that Innocent III commanded it for all heretics, bat what constitated technical heresy was not so easily determined. The statates of Raymond decreed it not only for heretics but for those who showed them favour. The conncil of Béziers in $\mathbf{1 2 3 3}$ demanded it for all reconciled converts not condemned to wear crosses, and those of Béziers in 1246 and Albi in 1254 prescribed it for all whom the inquisitors should condemn to imprisonment. This, finally, was admitted by legists us the invariable test, although St. Louis, when in 1259 he mitigated his ordonnance of 1229 , ordered confiscation not only for those who were condemned to prison, bat for those who contomaciously refused obedience to citations, and for those in whose houses heretics were found, his officials being instructed to ascertain from the inquisitors in all cases while pending whether the accused deserved imprisonment, and if so, to retain the sequestrated property. When he further provided, as a special grace, that the heirs shonld be restored to possession in cases where the heretic had offered himself for conversion before citation, had entered a religious order, and had worthily died there, he showed how universal confiscation had previously been, and how rathlessly the principle had been enforcen that a single act of heresy forfeited all ownership. ${ }^{8}$

According to the most lenient construction of the law, therefore, the imprisonment of a reconciled convert carried with it the confiscation of his property; and as imprisonment was the ordinary penance, confiscation was general. There may possibly have been exceptions. Six prisoners released in 1248 by Innocent IV had been in gaol for some time-some of them for four years and more after confessing heresy-and yet the liberal contribations to the Holy Land, which purchesed their pardon, show that they or their friends must have had control of property, unless, indeed, the money was raised on a pledge of the estates to be restored. So when Alaman de Rosix was condemned to imprisonment in 1248, the sentence provided for an annuity to be paid to a person designated and for compensation to be made for the rapine which he had committed, which would look as though property were left to him; but as he had for ten years been a contumacious and proscribed fugitive, these fines must have been takien out of his estate

- Harduin, vii. 203. Concil. Biterrens. ann. 1233, c. 4; ann. 1246, Append. c. 35. Concil. Albiens ann. 125t, a. 26. Goid. Fulood. Quast. Ir. Isambart, Ane. Loir Franr, i. 257. Arch. de l'Inq. de Carcass. (Dost, rxri. 263). 
in the hands of his state. Apparent exceptions such as these can be accounted for, and the proceedings of the Inquisition as a whole indicate that imprisonment and confiscation were inseparable. Sometimes even it is stated in sentences passed upon the dead, that they are pronounced worthy of imprisonment in order to deprive the heirs of succession to their estates. At a later date, indeed, Eymerich, who dismisses the whole matter briefly as one with which the inquisitor has no concern, spesks as though confiscation only took place when a heretic did not repent and recant before the sentence, bat his commentator Pegna easily proves this to be an error. Zanghino assumes as a matter of course that property is forfeited by the act of heresy. He points out that pecuniary penance cannot be imposed because the whole estate is gone, although there may be mercy shown at discretion with the assent of the bishop, and simple suspicion is not subject to confiscation.'

In the early zesl of persecution everything was swept away in wholessle seizure, but in 1237 Gregory IX assumed that the dowers of catholic wives ought to be exempt in certain cases; in 1247 Innocent IV made a rule that such dowers shodd not be included in future forfeitures, and in 1258 St. Louis accepted this rule. It was subject to serious limitations, however, since under the canon law the wife could not claim it if she had been cognisant of her husband's heresy when she married, and, according to some anthorities, if she had lived with him after ascertaining it, or even if she had failed to inform against him within forty deys after discovering it. As the children were incapable of inheritance, she only held the dower for life, after which it fell into the fisc. ${ }^{10}$

Although in principle confiscation was an affair of the state, the division of the spoils did not follow any invarisble rule. Before the organisation of the Inquisition, when the Waldenses of Strassburg were burnt, it is mentioned that their forfeited property was equally divided between the church and the secular authorities. Lucius III, as we have just seen, endeavoured to turn the whole forfeitures to the benefit of the charch. In the papal territory there conld be little question as to this, and Innocent IV, in his bull $A d$ extirpanda of 1252, showed disinterestedness in devoting the whole proceeds to the stimulation of persecution. One third was given to the local authorities, one third to the officials of the Inquisition, and one

- Arehives de l'Inq. de Careass. (Dast, rwi. 152). Berger, Registres d' Inroc IV, No. 1841. MSS. Bib. Nat fonds letin, No. 9992 . Lib. Sententt Imq. Tolosan. pp. 158-62. Archives de l'Inq. do Carcesss. (Dost, xuvii. 98). Eymeric Direct Inquis. pp. 66B-5 (ed 1607). Zenchini Tract. do Haret. a Iriii. xix. xrv.

to Archives do l'Evbcht do Bexiers (Dost, xri. 85). Potthast, No. 12713. Issmbert, i. 257. C. 14 Sexto, У. 2. Zanchini a Irv. Livres de Jostice at de Plet, liv. i titi iii. § 7. 
third to the bishop and inquisitor to be expended in the assault on heresy-provisions which were retained in the subsequent recensions of the bull by Alezander $\Gamma$ and Clement $I V$, while forfeited bail went exclusively to the inquisitor. Yet this was speedily held to refer only to the independent states of Italy, for in 1260 we find Alexander IV ordering the inquisitors of Rome and Spoleto to self the confiscated estates of heretics and pay over the proceeds to the pope himself; and a transaction of 1261 shows Urban IV collecting 320 lire from some confiscations at Spoleto."

At length both in the Roman province and elsewhere throughout Italy the custom settled down to a tripartite division among the local community, the Inquisition, and the papal camera-the reason for the latter, as given by Benedict XI, being that the bishops appropriated to themselves the share entrusted to them for the prosecution of heresy. In Florence, a transaction of 1283 shows this to be the received regulation; and documents of various dates during the next half-century indicate that it was the custom of the republic to appoint attorneys or trustees to take seisin of confiscated property in the name of the city, which in 1319 liberally granted its share for the next ten years to the construction of the charch of Santa Reparata. That the amounts were not small may be inferred from a petition of the inquisitors to the republic in 1299, setting forth that the holy office must have funds wherewith to pay its stipendiary officials, and therefore praying leave to invest in real estate the sums accruing to the Inquisition from this source, showing accumulations pradently garnered for the futare. The request was granted to the extent of 1,000 lire with the proviso that none of the city's share be taken. This precantion would seem to argue no great confidence in the integrity of the inquisitors; nor was the insinuation uncalled for. By this time the money-changers hod fairly occupied the temple, and it seemed almost impossible to preserve official honesty where persecution had become almost as much a financial speculation as a matter of faith. That plain-spoken Franciscan, Alvaro Pelayo, bishop of Silva and papal penitentiary, writing about the year 1395, bitterly reproaches those of his brethren who act as inquisitors, with their abuse of the funds accruing to the holy office. The papal division into thirds, he declares, was generally disregarded, the inquisitors monopolised the whole and spent it on themselves, or enriched their hindred at their pleasure. Chance has preserved in the Florentine archives some documents confirmatory of this accusation. It seems that in 1343 Clement VI obtained evidence that the inquisitors of both Florence and Lucca

" Hoffmenn, Gaschicizto der Inquisition, ii. 370. Lacii PP. III epist. 171. Innoc. PP. IV balle Ad extippanda, \$ 31. Ejusd. balle Super extippatione, 30 Meii 1254 (Ripoll i. 247). Alex. PP. IV bulle Diceretioni (Mag. Bull. Roman. i. 120). Potthest, Reg. Pont. No. 18200. 
were habitually defrauding the papal camera of its third of the fines and confiscations, and accordingly he sent to Pietro da Vitale, primicerio of Lucca, authority to collect the sums in arrears and to prosecute the embezzlers. How it fared with them we have no means of knowing, but the camera seems not to hare gained much in filling the vacancies thus occasioned. Fra Pietro di Aquila, a Franciscan of high standing, was appointed in Florence, who fell at once into the same evil ways, and within two years was obliged to fly from a prosecution by the primicerio, in addition to the charges of extortion brought against him by the republic. ${ }^{12}$

In Naples under the Angerins, when the Inquisition was first introduced, Charles of Anjou monopolised the confiscations with the same rapacity that was customary in France. As eariy as March 1270 we find him ordering his representatives in the Principato Ultra to account in detail for the estates of three heretics recently burnt at Benevento. In 1290 Charles II ordered the fines and confiscations to be divided into thirds, of which one should enure to the royal fisc, one be used for the promotion of the faith, and one be given to the Inquisition. Feudal lands, however, were to revert to the crown or to the immediate lord as the case might require. ${ }^{13}$

In Venice the compromise reached in 1289 between the signiory and Nicholas IV, whereby the republic permitted the introduction of the Inquisition, provided that all receipts of the holy office should be for the benefit of the state, and this arrangement seemed to have been maintained."

In the other Italian states the papal curia grew dissatisfied with its share when there was no longer a necessity of parchasing the co-operation of the civil power with a third of the spoils. It is a disputed point with the jurists when and how the change was effected; but in the first quarter of the fourteenth century the church succeeded in grasping the whole of the confiscations, which were divided equally between the Inquisition and the papal camera. The rapacity with which this source of income was exploited is illustrated in a case occurring at Pisa in 1804. The inquisitor Angelo da Reggio had condemned the memory of a deceased citizen and confiscated his property, part of which he then gave away, and part be sold at prices which the papal curia esteemed too low. Benedict XI thereupon ordered the bishop of Ostia not to panish the inquisitor, but to use freely the censures of the church in honting up the property in the hands of the holders

t2 Nich. PP. IV bolls Habet oestre, 3 Oct. 1290. Raynald. an. 1438, No. 24. Lami, Antichitd Toscare, pp. 588-9. Alv. Pelag. de Plancte Eccles. lib. i. art. 47. Archivio di Firense, Riformarione, classe v. No. 110 ; classe ri. Distinx. i. No. 39.

- Archivio di Napoli, registro 9, lett. C, tol. 90 ; regist. 51, lett. A, fol 9 ; regist. 98 , lett. B, tol 13 ; regiat. 113 , lett. 1 , fol 194 ; MSS. Chioccorelli, to viii.

" Albixio, Risposto al P. Paolo Sarpi, p. 25. 
and to take it from them. Finally, in 1438, Eugening IV generously handed back to the bishops the share of the papal camera in order to stimulate their slackness in persecation, and where the bishop was also the temporal lord of his see the confiscations were to be divided equally between him and the Inquisition. ${ }^{15}$

in Spain the rule was laid down that if the heretic were a clerk or a lay ragsal of the charch, the confiscation went to the church; if otherwise, to the temporal seignior. ${ }^{16}$

This greed for the plunder of the wretched rictims of persecution is pecaliarly repulsive as exhibited by the charch, and may to some ertent palliate the similar action by the state in countries where it was strong enough to seize and retain the spoils. The threats and coercion which at first were necessary to induce the temporal princes to confiscate the property of their heretical subjects soon became superfluous, and history has for examples of man's eagerness to profit by his fellows' misfortanes more deplorable than that of the valtures which followed in the wake of the Inquisition to batten on the ruin which it wrought.

Under the feudal system the confiscations were for the benefit of the seigneur haut-justicier. The rapid extension of the royal jurisdiction in the second half of the thirteenth century in France ended by practically placing them in the hands of the king, bat during the earlier and more profitable period there were quarrels over the spoils. After the treaty of Paris in 1229, which secured Lianguedoc to the crown, St. Lovis in granting fiefs in the newly acquired territories seems to hsve endesvoured to provide for these questions by reserving the confiscations for heresy. The pradence of this is shown by the suit brought by the marechan de Mirepoix, one of the few permenent families founded by the adventurers who accompanied De Montfort, who claimed the movables of all heretics captured in their lands, even if the goods were in the lands of the king-s demand which was rejected by the parlement of Paris in 1269. The bishops put in a claim to the confiscations of all real and personsl property of heretics living onder their jurisdiction, and at the council of Lille (Comtat Venaissin) in 1251 they threatened with excommunication any one who should dispute it. They really had some cause of complaint, for, in contravention of a canon of the conncil of Béziers in 1246, lands held of them in fief were thus being transferred to the king, and they found themselves losing instead of

13 Znechini Tract de Haret. ca nix. nxi xli Cf Pegno Comment in Eymeric. p. 659. Grandjean, Registre de Benoth, ri. No. 299. Raynald ann 1488, No. 24. Yet it must be pleced to Benedict's credit thet in 1304 he enthorised Fn Bimane, inquisitor of Rome, to restore confiscations unjortly made by his prodeceseors, and to moderate panishments inflicted by them if he considered them too severe. (Grandjean, No. 474.)

10 Alonsi de Spins Fortalicii Fidsi lib. ii consid ri (ed. 1594, tol. 74). 
grining by persecution. St. Louis finally listened to their grievances, and, about 1255, entered into an agreement whereby all such lands were divided equally between the bishop and the king, with a right on the part of the prelate to buy out within two months the royal share at a price fired by arbitration. If this right was not exercised, the king was bound within a year and a day to pass the lands out of his hands into those of a person of the same condition as the former tenant, to be held under the same terms of service or villenage; but all movables were declared to belong unreservedly to the crown. What an ample harvest was afforded to the lawyers by the intricate quarrels arising from this wholesale spoliation, is illustrated by a suit brought by the bishops of Rodez for some lands held by the crown as heretic confiscations. After dragging on for thirty years it reached the parlement of Paris, which coolly annulled all the proceedings on the ground that those who had acted for the crown had lacked the proper anthority. Almost equally protracted and confused was a suit between Eleanor de Montfort, conntess of Vendome, and the king over the lands of Jean Bandier and Raymond Calverie. The confiscation occurred in 1300 , and the suit was still dragging on in 1927, to be finally compromised in 1395.17

By a special transaction of 21 Dec. 1264, between St. Louis and Bernard de Combret, bishop of Albi, the prelate of that enjoyed one half of all the confiscations within it, with the further advantage that the remainder of real estate passed into his possession if the king did not sell his share within a twelvemonth, and became his property if not sold within three years; and in the acconts of the royal procureurs des encours of Carcassonne we constantly find the confiscations in Albi shsied with the bishop. Although between St. John's day of 1322 and 1323 this share in money amounted only to 160 livres, there were times when it was much grester. About the year 1300, Bishop Bernard de Castanet generously gave to the Dominican church of Albi his portion of the estates of two citizens, Guillem Aymeric and Jean de Castanet, condemned after death, which amounted to more than 1,000 livres. This privilege of the see of Albi may perhaps have arisen from a specisl deputation of inquisitorial powers granted in 1247 by Innocent IV to Bishop Bertrand, for in the following year, 1248, we see the latter doing a thriving basiness in selling commutations of confiscations to condemned heretics who repented. It is true that when Alfonse of Poitiers in 1258 endearoured to speculate in the same way by allowing heretics to redeem their confiscated property,

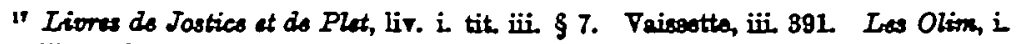
317 ; iii. 1126-9 ; ii. 1440-2. MS8. Bib. Nat. fonds latin, No. 11817. Concil Insalan. enn. 1251 a 3. Concil Biterrens ann. 1246 c. \&. Balas. Concil Narbonn. append pp. 96-99. Coll. Dost, I0r7. 48. Ct Berger, Registres d'Irrocent IV, No. 154844 1517-18. Molinier, L'Irquirition dans 4 midi de la France, p. 101. 
he was compelled to desist by the earnest representations of the archbishop of Narbonne and bishop of Toulouse, who declared that this would lead to the scandal of the faithfal and the destruction of religion; bat doabtless the bishops of Albi continued to claim and exercise a control over the conisscations which led the hing to divide the spoils with them. This division led to constant quarrels. In rain Philippe le Bel in 1307 ordered the observance of the agreement with restitution for any infractions. In 1316 we find the bishop claiming properties which had not been sold within the three years, and Armand Assalit, the royal procureur des encours, argaing that he had been prevented from effecting sales by just and legitimste causes, when the seneschal Aymeric de Croso decided that the impediments had been legitimate and that the rights of the king were not forfeited. The heads of the church of Albi evidently had a keen eye for the profitable side of persecution. ${ }^{1 s}$

All prelates were not as rapacious as those of Albi, one of whoin we find still, in 1328, complaining of the evasions resorted to by the victims to save a fragment of their property for their families, but the princes and their representatives were relentless in grasping all they could lay their hands on. I have mentioned that as soon as a suspect was cited before the Inquisition, his property was sequesirated to await the result, and proclamation made to all his debtors and those who held his effects to bring everything to the king. Charles of Anjou carried this practice to Naples, where a royal order in 1269 to arrest sixty-nine heretics contains instructions to seize simultaneously their goods, which are to be held for the king. So assured were the officials that condemnation would follow trial, that they frequently did not await the result, but carried out the confiscation in advance. This abuse was coeval with the founding of the Inquisition. In 1237 Gregory IX complained of it and forbade it, but to little purpose, for in 1246 the conncil of Béziers again prohibited it, unless, indeed, the offender had knowingly adhered to those who were bnown to be heretics, in which case apparently it was sanctioned. When, in 1259, St. Louis mitigated the rigours of confiscation, he indirectly forbade this wrong by instructing his officials that when the accused was not condemned to imprisonment, they shonld give him or his heirs a bearing to reclaim the property ; but if there was any suspicion of heresy it was not to be restored without taking security that it should be surrendered if anything was proved within five years, during which period it was not to be alienated. Yet still the outrage of confiscation before conviction continued with sufficient frequency to indace Boniface VIII to embody its prohibition in the canon law. Eren this did not put a stop to it. The Inquisition

1" Hanréan, Bernard Delicicux, p. 21. Coll Dost, xrriv. 189. Bern Gridon. Bist. Conv. Albiens. Vaissette, iii pr. 467, 500. Arch. de l'Inq. de Carcasen (Doat, Ixxi. 143, 146). Coll Dost, Irriv. 131, 135. 
had so habituated men's minds to the belief that no one escaped who had once fallen into its hands, that the officials considered themselves safe in acting upon the presumption. By an unusual coincidence we have the data from various sources in a single casse of this kind which is doubtless the type of many others. In the prosecutions at Albi in 1300 a certain Jean Baudier was first examined January 20, when he acknowledged nothing. At a second hearing, February 5, he confessed to acts of heresy, and he was condemned March 7, jet his confiscated property was sold January 29 , not only before his sentence, but before his confession. ${ }^{19}$

The ferocious rapacity with which this process of confiscation was carried on may be conceived from a report made by Jean d'Arsis, seneschal of Ronergue, to Alfonse of Poitiers about 1253, as an evidence of the zeal with which he was guarding the interests of his suzersin. The bishop of Rodez was conducting a vigorous episcopal inquisition, and at Najac had handed over a certain Hugues Paraire as a heretic, whom the seneschal burnt 'incontinently;' and collected over 1,000 litres tournois from his estate. Hearing subsequently that the bishop had cited before him at Rodez six other citizens of Najac, D'Arsis hastened thither to see that no frand was practised on the connt. The bishop told him that these men were all heretics, and that he would gain for the connt 100,000 sols from their confiscation, but both he and his assessors begged the seneschal to forego a portion to the culprits or their children, which that loyal servitor bluntly refused. Then the bishop, following evil consel and in frand of the rights of the count, endeavoured. to elude the forfeitures by condemning the heretics to some lighter penance ; the seneschal, however, knew his master's rights, and seired the property, after which he allowed some pittance to the penitents and their children, reporting that in addition to this he was in possession of about 1,000 livres, and he winds ap by advising the count, if he wishes not to be defrauded, to appoint some one to watch and supervise the further inquisitions of the bishop. On the other hand, the bishops complained that the officials of Alfonse permitted heretics, for a pecuniary consideration, to retain a part or the whole of their confiscated property, or else condemned to the flames those who did not deserve it in order to seize their estates. These frightful abuses grew 80 unbearable that in 1254 the officials of Alfonse, inclading Gui Foncoir, endeavoured to reform them by issaing general regulations on the subject, but the matter was one which in its inherent nature scarce admitted of reform. Yet Alfonse with all his greed was not unwilling to share the plonder with those

- Archives de l'Erteché d'Albi (Dost, Irr. 35, 89). Lres Olim, i 556. Archivio di Napoli, regist. 4, lett B, fol. 47. Concil. Biterrens ann. 1246, c. 3. Isembert, i. 257. c. 19 Sexto, v. 2 MSS. Bib. Nat. fonds latin, No. 11847. Coll Doat, Irrv. 68. Molinier, L'Inq. dars le midi de la Frarce, p. 102. 
who secured it for him, and several of his not wholly disinterested liberalities of this kind are on record. In 1268 we have a letter of his assigning to the Inquisition a revenue of 100 livres per annum on the confiscated estate of a heretic; and in 1270 another confirming the foundation of a chapel from a similar source..$^{20}$

Nothing could exceed the minute thoroughness with which every fragment of a confiscated estate was followed up and seized. The account of the collections of confiscated property from 1302 to 1313 by the procureurs des encours of Carcassonne is extant in manuscript, and shows how carefully the debts due to the condemned were looked after, eren to a fer pence for a messure of corn. In the case of one wealthy prisoner, Guillem de Fenasse, the estate was not wound up for eight or ten years, and the whole number of debts collected amounts to 859 , in sums ranging from five deniers apwards. As the collectors never credit themselves with amounts paid in discharge of debts due by these estates, it is evident that the rule that a heretic could give no valid obligations was strictly construed, and that creditors were shamelessly cheated. In this seizure of debts, the nobles asserted a right to claim any sums due by debtors who were their vassals; bat Philippe de Valois, in 1329, decided that when the debts were payable at the domicile of a heretic they enured to the royal fisc irrespective of the allegiance of the debtor. Another illustration of the remorseless greed which seized everything is found in a soit decided by the parlement of Paris in 1302. On the death of the chevalier Guillem Prunelle and his wife Isabelle, the guardianship of their orphans would legally vest in the next of kin, the chevalier Bernard de Montesquien, but he had been burnt some years before for heresy, and his estate of course confiscated. The seneschal of Carcassonne insisted that the guardianship which thus subsequently fell in, formed part of the assets of the estate, and he accordingly assumed it ; but a nephew, an esquire Bernard de Montesquieu, contested the matter, and finally obtained a decision in his favour. ${ }^{2 i}$

Equal care was exercised in recovering alienated property. As, in obedience to the Roman lsw of majestas, forfeitare occurred ipso facto as soon as the crime of heresy was committed, the beretic could convey no legal title, and any assignments which he might. have made were void, no matter through how many hands the property might have passed. The holder was forced to surrender it, nor could he demand restitation of what he had paid unless the money or other consideration were found among the goods of the heretic. The eagerness with which the rigour of the law was

- Boutaric, Saint Lovis et Alfonse de Poitiers, Paris, 1870, pp. 455-6. Doncis, - Ines Sonres do l'histoire de l'Inquisition' (Bevue des Questions Historiques, actobre 1881, p. 486). Coll Doat, roxii. 51, 64.

$n$ Archives de l'Evachs d'Albi (Dost, raiii. 207-72). Coll Doat, xrxy. 93. Les Otim, ii. 111. 
enforced may be estimated from a case which occurred in 1272. Charles of Anjou had written from Naples to his viguier and sousviguier at Marseilles, telling them that a certain Maria Roberta, before condemnation to imprisonment for heresy, had sold a house which was subject to contiscation; this he ordered them to seize, to sell by auction, and to report the proceeds, but they neglected to do so. The viguiers were changed, and now the unforgetfol Charles writes to the new officisls repeating his orders, and holding them personally responsible for obedience. At the same time he writes to his seneschal with instructions to look after the matter, as it lies very near to his heart."

Perhsps nothing contribated more to the consolidation of the royal supremacy in the south of France than the change of ornership which threw into new hands so large a proportion of the property of Languedoc. In the domains of the crown the forfeited lands were granted to favourites or sold at moderate prices to those who thas became interested in the new order of things arising from the fall of the house of Toulouse. The royal officials grasped everything on which they could lay their hands whether on the excuse of treason or of heresy; and although the rightmindedness of Louis IX caused an inquest to be held in 1262 which restored a vast amount of property illegally held, this was but a small fraction of the whole. To assist his parlement in settling the innomerable cases which arose, he ordered in 1260 the charters and letters of greatest importance to be sent to Paris. Those of each of the six sénéchaussées filled a coffer, and the six coffers were deposited in the treasury of the Sainte Chapelle. In this process of absorption the case of the extensive viscounty of Fenouilledes may be taken as an illustration of the zeal with which the Inquisition co-operated in securing the political advantages desired by the crown. Fenouilledes had been seized during the crasades of De Montfort and given to Nunez Sancho of Roussillon, from whom it passed, through the king of Aragon, into the hands of Saint Lonis. In 1264, Bestrix, widow of Hugues, son of the former Viscount Pierre, applied to the parlement for her rights of dower and those of her children. Immedistely the inquisitor, Pons de Poyet, commenced a prosecution against the memory of Pierre, who had died more than twenty jears previously, in the bosom of the church, and had been buried with the templars of Mas-Deu after receiving the last sacraments. Pons de Poyet found no diffculty in condemning him as suspect of heresy for having associated with heretics, his bones were dug up and burnt, and the parlement rejected the claims of his daughter-in-law and grandchildren.

$=$ Archidiec. Gloss. sup. c. 19 Sexto, v. 2. Archivio di Napoli, regist. 18, lett. C, tol. 77, 78. The. English let of telong was also retrosetive, and all alinations subsequent to the commission of the crime wore void. Brecton, lib. iii. tract. ii. c. 13, No. 8. 
Pierre, the eldest of these, in 1300, again put forward a claim for the ancestral estates, and Boniface VIII espoused his quarrel with the object of giving trouble to Philippe le Bel, but although the affair was porsued for some years the inquisitorial sentence held good. It was not only the actual heretics and their descendants who were dispossessed. The land had been so deeply tinctured with Catharism and Waldensianism, that there were few indeed whose ancestors could not be shown by the records of the Inquisition to have incurred the fatal taint of associating with them. ${ }^{23}$

The rich bourgeoisie of the cities were ruined in the same way. Some inventories have been preserved of the goods and chattels sequestrated, as when in December 1290 and January 1800 twentyfive or thirty of the wealthiest citizens of Albi were suddenly seized and condemned, which show how thoroughly everything was swept into the maelstrom. That of Raymond Calverie, a notary, gives as every detail of the plenishing of a well-to-do burgher's household-every pillow, sheet, and coverlet is enumerated, every article of kitchen gear, the salted provisions and grain, even his wife's little trinkets. His farm was subjected to the same minuteness of seizure. We have a similar insight into the stock of goods of Jean Baudier, a rich merchant. Every fragment of stuff is duly measured off-cloths of Ghent, Ypres, Amiens, Cambrai, St. Omer, Ronen, Paris, Montcornet, \&rc., with their valuation, pieces of miniver and other articles of trade. His town house and farm were inventoried with the same conscientions care. It is easy to see how prosperous cities were reduced to poverty, how industry languished, and how the independence of the municipalities was broken into subjection in the awfol uncertainty which hung over the head of every man.4

In this chaos of plunder we may readily imagine that those who were engaged in such work were not over-nice as to securing a share of the spoliations. In 1304 Jacques de Polignac, keeper of the inquisitorial gaol at Carcassonne, and several of the officials employed on the confiscations, were found to have converted and detained a large amount of valuable property, including a castle, farms and other lands, vineyards, orchards and movable effects, all

- Vuissette, iii. 862,496 ; iv. 104-5, 211 Archives de l'Eveché de Beziers (Dost, rxi. 35). Bengrot, Les Olim i 580, 1089-30. Coll Dost wrifi. 1. The extent of the change of propriotorship is well illastrated by a list of the lands and rents confiscated for heresy to the profit of Philippe de Montfort trom his raseals. It embraces fiefs and other properties in Lastrec, Montredon, Senegats, Rebastain, and Loveur. The knights and gentlemen and peasants thus stripped are all named with their offences; one had died a heretic, another was hereticated on his deathbed, a third was condemaned for heresy, a fourth hed been burnt at Lavaur, while in other cases the tather, or mother, or both, had been herotics (Dost, xwnii. 258-68). Many examples of sales and donstions hare been preserved in the Dont collection. I maj

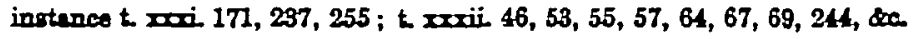

"I Coll Doat, xxrii 309, 316. 
of which they were compelled to disgorge and suffer punishment at the king's pleasure. 25

It is pleasant to turn from this cruel greed to a case which excited mach interest in Flanders at a time when in that region the Inquisition had become so nearly dormant that the usages of confiscation were almost forgotten. The bishop of Tournay and the vicar of the Inquisition condemned at Lille a number of hereties, who were duly borned. They confiscated the property, claiming the movables for the church and inquisitor, and the realty for the fisc. The magistrates of Lille boldly interposed, declaring that among the liberties of their town was the privilege that no burgher could forfeit both body and goods; and, acting for the children of one of the victims, they took out apostoli and appesled to the pope. The counsellors of the suzerain, Philippe le Bon of Burgundy, with a clearer perception of the law, claimed that the whole confiscation enured to him, while the ecclesiastics declared the rale to be invariable that the personalty went to the church and only the real estate to the fisc. The triangular quarrel threatened long and costly litigation, and finally all parties agreed to leave the decision to the duke himself. With rare wisdom, in 1430 , he settled the matter with general consent by deciding that the sentence of confiscation should be treated as not rendered, and the property be left to the heirs, at the same time expressly declaring that the rights of church, inquisition, city, and state, were reserved without prejudice, in any case that might arise in future, which was, he said, not likely to occur. Unfortunately for his repatation, he did not manifest the same disinterestedness in 1460 in the terrible persecution of the sorcerers of Arras, when the movables were confiscated to the episcopal treasury, and he seized the landed property in spite of the privileges alleged by the city. $\$$

In addition to the misery inflicted by these wholesale confiscations on the thousands of innocent and helpless women and children thus stripped of everything, it would be almost impossible to exsggerate the evil which they entailed upon all classes in the business of daily life. All safeguards were withdrawn from every transaction. No creditor or purchaser could be sure of the orthodory of him with whom he was dealing; and even more than the principle that ownership was forfeited as soon as heresy had been committed by the living, the practice of proceeding against the memory of the dead, after an interval virtaally anlimited, rendered it impossible

2 Las Olim, ii. 147. Dont, nvi. 253.

" Archives Génerales de Belgique, Papiers d'Etat, 7. 405. Memoires de Jacques du Clercq, liv. iv. ch. 4, 14. In Arras, a charter of 1395, confirmed by Charles $\nabla$ in 1369, protected the borghers trom confiscation when condemoed by any competent tribonal (Doverger, La Fauderis dans les Etats de Philippo lo Bom, Arras, 1885, p. 60) 
for any man to feel secure in the possession of property, whether it. had descended in his family for generations or had been acquired within an ordinary lifetime.

The prescription of time against the charch had to be at least forty years-against the Roman church, a hundred. Though some legists held that proceedings against the deceased had to be commenced within five years after death, others asserted that there was no limit, and the practice of the Inquisition shows that the latter opinion was followed. The prescription of forty years' possession by good catholics was further limited by the conditions that they must at no time have had a knowledge that the former owner was a heretic, and, moreover, he must have died with an unsullied reputation for orthodory-both points which might cast a grave doubt on titles. ${ }^{27}$

Prosecution of the dead by the inquisitorial process was a mockery in which virtually defence was impossible and confiscation inevitable. How unexpectedly the blow might fall is seen in the case of Gherardo of Florence. He was rich and powerful, a member of one of the noblest and oldest honses, and was consul of the city in 1218. Secretly a heretic, he was hereticated on his deathbed between 1246 and 1250, bat the matter lay dormant until 1313, when Fra Grimaldo, the inquisitor of Florence, brought a successfal prosecution against his memory. In the condemnation were included his children, Ugolino, Cante, Nerlo, and Bertuccio, and his grandchildren, Goccia, Coppo, Fra Giovanni, Gherardo prior of S. Quirico, Goccino, Baldino, and Marco-not that they were heretics, but that they were disinherited and subjected to the disabilities of descendants of heretics. Where such proceedings were hailed as pre-eminent exhibitions of holy zeal, no man could feel secure in his possessions, whether derived from descent or purchese. ${ }^{20}$

Not only were all salienations made by heretics set aside and the property wrested from the purchasers, but all debts contracted by them and all hypothecations and liens given to secure loans were void. Thus doubt was cast upon every obligation that a man

z C. 6, 8, 9, 14, Bexto, ii. 28. Eymeric. Direct. Inquil. pp. 570-2. Zenchini Tract de Haret o xriv. Severe as was the contemporary English low against felony, it.hed at least this concession to justice, thet 8 felon hed to be convicted in his litetime; his death before conviction thas prevented confiscation (Bracton, lib. iii. trect ii. cesp. 18, No. 17).

- Lemi, Artichitd Tosense, pp. 497, 536-7. It is trot that when, in 1885, Henri de Chamey, inquisitor of Carcessonne, sent to the papal court the depositions against the memory of eighteen persons accused of heretical scts committed between 1284 and 1290, and asked for instructions, the decision wes that no reliance fras to be pleced on the testimony of witnessea who mostly contradicted themselves and who only strore to what they had heard some ffty years before (Vaissette, iv. 184). Fet the mero collection of such evidence for such a puppose is a sufficient illustration of the system. 
could enter into. Even when St. Louis softened the rigour of confiscation in Languedoc, the utmost concession he would make was thet creditors should be paid for debts contracted by culprits before they became heretics, while all claims arising subsequently to an act of heresy were rejected. As no man could be certain of the orthodory of another, it will be evident how much distrast must have been thrown apon every bargain and every sale in the commonest transactions of life. The blighting influence of this upon the development of commerce and industry can readily be perceived, coming as it did at a time when the commercial and industrial movement of Europe was beginning to usher in the dawn of modern colture. It was not merely the intellectual striving of the thirteenth century that was repressed by the Inquisition, the progress of material improvement was seriously retarded. It was this, among other incidents of persecution, which arrested the promising civilisation of the sonth of France and transferred to England and the Netherlands, where the Inquisition was comparatively unknown, the predominance in commerce and industry which brought freedom and wealth and power and progress in its train."

The quick-witted Italian commonwealths, then rising into mercantile importance, were keen to recognise the disabilities thus inflicted upon them. In Florence a remedy was sought by requiring the seller of real estate always to give security against possible future sentences of confiscation by the Inquisition-the security in general being that of a third party, although there must have been no little difficulty in obtaining it, and though it might likewise be invalidated at any moment by the same cause. Even in contracts for personalty security was also often demanded and given. This was at lesst only replacing one evil by another of scarcely less magnitude, and the trouble grew so intolerable that a remedy was sought for one of its worst features. The republic solemnly represented to Martin IV the scandals which had occurred, and the yet grester ones threstened in consequence of the confiscation of the real estate of heretics in the hands of bona fide purchasers, and by a special ball of 22 Nor. 1283 the pontiff graciously ordered the Florentine inquisitors in future not to seize such property. ${ }^{20}$

The princes who enjoyed the results of confiscations recognised that they carried with them the correlative duty of defraying the expenses of the Inquisition ; indeed, self-interest alone would have prompted them to maintain in a state of the highest efficiency an instrumentality so profitable. Theoretically it conld not be denied that the bishops were liable for these expenses; but, as Gui Foucoir

Denchini, Tract de Haret. c. Irvii. Isambert, i. 257.

- Lami, Antichitd Toscare, p. 593. Archivio di. Firense, Biformarione, classe F. No. 110. 
(Clement IV) remarks, their hands were tenacious and their purses constipated, and as it was useless to look to them for resources he advises that the pecuniary penances be used for the purpose, providing it be done decently and without scandalising the people. Throughout Lombardy and central Italy, as we have seen, this resource rendered the Inquisition fully self-supporting, and the inquisitors were eager to make business out of which they could reap a harvest of fines and confiscations. In Venice the state defrayed all expenses and took all profits. In Naples the same policy was at first pursued by the Angevin monarchs, who took the confiscations and, in addition to maintaining prisoners, paid to each inquisitor one augustale ( $\frac{1}{\mathrm{~J}} \mathrm{lb}$. of gold) per diem for the erpenses of himself and his associate, his notary and three familiars with their horses. These stipends were assigned upon the Naples castoms on iron, pitch, and salt. The orders for their payment ran only for four months at a time, and had to be renewed. There was considerable delay in the settlements, and the inquisitors hed substantial cause of complaint, although the officisls were threatened with fines for lack of promptness. In 1272, however, I find a letter issued to the inquisitor Fra Mattoo di Castellamare providing him with a year's salary, payable six months in advance. When, as mentioned above, Charles II in 1290 divided the proceeds according to the pepal prescription, he liberally continued to contribute to the expenses, though on a reduced scale. In letters of $16 \mathrm{May} \mathrm{1294,} \mathrm{he}$ orders the payment to Fra Bartolomeo di Aquila of foor tareni per diem (the tareno was $\frac{1}{36}$ oz. of gold); and 7 July of the same year, he provides that five ounces per month be paid to him for the expenses of his official family."

In France there was at first some question as to the responsibility for the charges attendant upon persecution. The duty of the bishops to suppress heresy was so plain that they could not refuse to meet the expenses, at least in part. Before the establishment of the Inquisition this consisted almost wholly in the maintenance of imprisoned converts, and at the council of Toulonse in 1229 they agreed to defray this in the case of those who had no money, while those who had property to be confiscated they claimed should be supported by the princes who obtained it. This proposition, like the subsequent one of the council of Albi in 1254, was altogether too cumbrous to work. The statutes of Raymond in 1294, while dwelling elaborately on the subject of confiscation, made no provision for meeting the cost of the new Inquisition, and the matter remained unsettled. In 1237 we find Gregory IX complaining

3 Goid. Folcod. Quast. iii. Archivio di Napoli, regist. 6, lett. B, fol 35; reß. 10, lett. $B$, fol. $6,7,96$; reg. 11 , lett. C, tol 40 ; reg. 13, lett. $\triangle$, tol 212 ; reg. 51 , lett. $\Delta$, fol 9 ; reg. 71 , lett. 11 , tol. $382,385,440$; reg. 98, lett. B, fol. 13; reg. 113, lett. $A$, tol 194 ; reg. 253 , lett $A$, tol 63 ; MSS. Chiocerello, t. viii. 
that the royal officials contributed nothing for the support of the prisoners whose property they bad confiscated. When in 1246 the council of Béziers was assembled, the cardinal legate of Albano reminded the bishops that it was their business to provide for it, according to the instructions of the council of Montpellier, whose proceedings have not reached us. The good bishops were not disposed to do this. They claimed that prisons should be boilt at the expense of the recipients of the confiscations, and suggested that the fines should be used for their maintenance and for that of the inquisitors. The piety of St. Louis, however, would not see the good work halt for lack of the necessary means; with a mare worldly prince we might assume that he recognised the money spent on inquisitors as profitably invested. In 1248 we find him defraying their expenses in all the domains of the crown, and he piously assumed the cost of the prisons and prisoners, in addition to which, in 1244, he ordered his seneschal of Carcassonne to pay out of the confiscations ten sols per diem to the inquisitors for their expenses. It may fairly be presumed that Count Raymond contributed with a grudging hand to the support of an institution which he had opposed as long as he dared; but when he was succeeded in 1249 by Jeanne and Alfonse of Poitiers, the latter politic and avaricious prince $88 \mathrm{w}$ his account in stimulating the zesl of those to whom he owed his harvest of confiscations. Not only did he defray the cost of the fixed tribunals, but his seneschals had orders to pay the expenses of the inquisitors and their familiars in their movements throughout his territories. Charles of Anjou, who was equally greedy, found time amid his Italian distractions to see that his seneschal of Provence and Forcalquier kept the Inquisition supplied on the same basis as did the king in the royal dominions. ${ }^{32}$

Large as were the returns to the fisc from the industry of the Inquisition, the inquisitors were sometimes disposed to presume upon their usefulness and to spend money with a freedom which seemed annecessary to those who paid the bills. Even in the fresh zeal of 1242 and 1244, before the princes had made provision for the holy office, and while the bishops were yet zealously maintaining their claims to the fines, the lurury and extravagance of the inquisitors called down upon them the reproof of their own order, as expressed in the Dominican provincial chapters of Montpellier and Arignon. It would be of course unjust to cast such reproach upon all inquisitors, but no doubt many deserred it, and there were numerous ways in which they could supply their wants, legitimste

- Concil. Tolosan ann. 1229, c. 9. Concil ATbiens ann. 1254, c. 24. Ekrduin, vii. 415. Archives de l'Evéché do Béziers (Dost, nai. 35). Concil. Biterrens. ann. 1246, c. 22. D. Bouquet, to xri pp. 262, 264, 266, 278, da Vaissette, ed. Privst, viii. 1206. Archives de l'Inq. de Carcass. (Dont, 00i, 250). Archivio di Nepoli, regist 20 , lett. B, tol. 91 ' 
and otherwise. It might indeed be a carions question to determine the source whence Bernard de Caur, who presided over the tribunal of Toulouse until his death in 1252, and who as a Dominican could have owned no property, obtained the means which ensbled him to be a great benefactor to the convent of Agen, founded in 1249 . Even Alfonse of Poitiers sometimes grew tired of ministering to the wishes of those who served him so well. In a confidential letter of 1268 he complains of the vast expenditures of Pons de Poyet and Etienne de Gâtine, the inquisitors of Toulouse, and instructs his agent to try to persuade them to remove to Lavaur, where less extravagance might be hoped for. He offered to put at their disposal the castle of Lavaur, or any other that might be fit to serve as a prison; and at the same time he craftily wrote to them dirent, explaining that, in order to enable them to extend their operaticns, he would place an enormous castle in their hands. ${ }^{3}$

Some very curious details as to the expenses of the Inquisition, from St. John's day 1322 to 1323 , thas defrayed from the confiscations, are afforded by the accounts of Arnand Assalit, procureur des encours of Carcassonne and Béziers, which have fortunately been preserved. From the sums thus coming into his hands the procureur met the outlays of the Inquisition to the minutest itemthe cost of maintaining prisoners, the hunting-up of witnesses, the tracking of fugitives, and the charges for an auto de fé, including the banquets for the assembly of experts, and the saffron-colonred cloth for the crosses of penitents. We learn from this that the wages of the inquisitor himself were 150 livres per annum, and also that they were very irregularly paid. Friar Otbert had been appointed in Lent 1316, and thas far had received nothing of his stipend; but now, in consequence of a special letter from King Charles le Bel, the whole accumulation for six years, amounting to 900 livres, is paid in a lamp. Although by this time persecution was slackening for lack of material, the confiscations were still quite profitable. Assalit charges himself with 2,219 livres 7 sols 10 deniers, collected during the year, while his outlay, including heary legal expenses and the extraordinary payment to Friar Otbert, amounts to 1,168 livres 11 sols 4 deniers, leaving about 1,050 livres of profit to the crown. ${ }^{2}$

Persecution, as a steady and continuons policy, rested, after all, upon confiscation. It was this which supplied the fuel to keep up

- Molinier, L'Inq. dars lo midi de la France, p. 308. Bern Gridon. Fundat. Conturt Predic (Martene, Thesaur. vi. 481). Boutaric, Saint Louis et Alforse de Poitiers, pp. 456-7.

4 Coll. Dout, Ixxiv. 189. In 1317 the result had been much less. We heve the recript of the royal treasurer of Carcassonne, Lotheire Blanc, to Araend Assalit, deted 24 Sept. 1317, tor collections during the year ending the previous St. John's day, amounting to 495 limres 6 solg 11 deniers, being the balence after deducting wages and expensen (Doat, xriv, 141). 
the fires of zeal; and when it was lacking, the business of defending the faith languished lamentably. Catharism disappeared under the brilliant aggressiveness of Bernard Gui, the culminating point of the Inquisition was prssed, and thenceforth it steadily declined, although there were still occasional confiscated estates over which king, prelate, and noble quarrelled for some years to come. ${ }^{35}$ The spiritual Franciscans, Dulcinists, and Fraticelli were mendicants who held property to be an abomination; the Waldenses were poor folk-mountain shepherds and lowland peasants-and the only prises were an occasional sorcerer or usurer.

The intimate connerion between the activity of persecuting zeal and the material result to be derived from it is well illustrated in the failure of the first attempt to extend the Inquisition into Franche-Comté. John, count of Burgundy, in 1248, represented to Innocent IV the alarming spread of Waldensianism throughout the province of Besançon, and begged for its repression. Apparently the zeal of Connt John did not lead him to pay for the pargation of his dominions, and the plunder to be gained was inconsiderable, for in 1255 Alezsnder IV granted the petition of the friars to be relieved from the duty, in which they averred that they had exhsusted themselves fruitlesaly for lack of money. The same lesson is taught by the want of success which attended all attempts to establish the Inquisition in Portugal. When in 1376 Gregory XI ordered the bishop of Lisbon to appoint a Franciscan inquisitor for the kingdom, recognising apparently that there would be amall receipts from confiscations, he provided that the incumbent should be paid a salary of 200 gold florins per annum, sssessed upon the various sees in proportion of their forced contributions to the papsl camera. The resistance of inertis which rendered this command resultless doubtless arose from the objection of the prelates to being thus tared; and the same may be said of the efforts of Boniface IX when he appointed Fray Vicente de Lisboa as inquisitor of Spain, and ordered his expenses to be defrayed by the bishops.

Eymerich, writing in Aragon about 1975, says the source whence the expenses of the Inquisition should be met is a question which had been long debated and never settled. The most popular view among churchmen was that the burden should fall on the temporal princes, since they obtsined the confiscstions, and should rocept the charge with the benefit; but in these times, he sorrowfully adds, there are few obstinate heretics, fewer still relapsed, and scarce any rich ones, so that, as there is little to be gained, the princes are not willing to defray expenses. Some other mesns ought

Dost, nuxv. 79, 100.

- Potthast, Na 18000, 15995. Monteiro, Biotoria da Sarta Inquiricado, p. i lib. ii.a. $84,35$. 
to be found, but of all the derices which have been proposed each has its insuperable objection; and he concludes by regretting that an institution so wholesome and so necessary to Christendom should be $s 0$ badly provided. ${ }^{37}$

It was probably while Eymerich was saddened with these unpalatable truths that the question was raisung itself in the most practical shape elsewhere. In 1375 Gregory XI persuaded King Frederic of Sicily to allow the confiscations to enure to the benefit of the Inquisition, so that funds might not be lacking for the prosecution of the good work. At the same time he made a vigorons effort to exterminate the Waldenses, who were multiplying in Danphiné. There were prisons to be built and crowds of prisoners to be supported, and he directed that the expenses should be defrayed by the prelates, whose negligence had given opportunity for the growth of heresy. Although he ordered this to be enforced by excommunication, it would seem thet the constipated parses of the bishops could not be relared, for soon after we find the inquisitor laying claim to a share in the confiscations, on the reasonable ground of his having no other source whence to defray the necessary expenses of his tribunal. The royal officials insisted on keeping the whole, and a lively contest arose, which was referred to King Charles le Sage. The monarch dutifully conferred with the holy see, and in 1378 issued an ordonnance retaining the whole of the confiscations, and assigning to the inquisitor a yearly stipend-the asme as that paid to the tribunals of Tonlouse and Carcassonneof 190 liveres tournois, out of which all of the expenses of the Inquisition were to be met, with the proviso that, if the allowance was not regularly paid, then the inquisitor should be at liberty to detain a portion of the forfeitures. No doubt this arrangement was observed for a time, but it lspsed in the terrible disorders which ensued on the insanity of Charles VI. In 1409 Alexander V left to his legate to decide whether the inquisitor of Dauphine should receive 900 gold florins a year, to be levied on the Jews of Arignon, or ten florins a year from each of the bishops of his extensive district, or whether the bishops should be compelled to support him and his officials in his journeys through the country. These precarious resources disappeared in the confusion of the civil wars and invasion which so nearly wrecked the monarchy In 1432, when Friar Pierre Fabri, inquisitor of Embrun, was summoned to attend the council of Basel, he excused himself on account of his preoccupations with the stubborn Waldenses, and also on the ground of his indescribable poverty, ' for never have I had a penny from the church of God, nor have I a stipend from any other source.' 3

Tr Eymeric. Direct. Inquis. Pp. 6523.

- Ragneld Arrat ann 1875, No. 26. Wadding, Annal. Afinor. ann. 1375, No. 21, 22 ; ann. 1409, No. 13. Isambert, v. 491. Martane, $A$ mpl Coll. viii 161-8. 
Of course it would be anjust to say that greed and thirst for plonder were the impelling motives of the Inquisition, bat we are perfectly safe in asserting that but for the gains to be made ont of fines and confiscations its work would have been mach less thorough, and that it would have sunk into comparative insignificance as soon as the first frantic zeal of bigotry had exhausted itself. This zeal might have lasted for a generation, to be followed by a period of comparative inaction, until a fresh onslaught would have been excited by the recrudescence of heresy. Under a succession of such spasmodic attacks Catharism would probably have never been completely rooted out. By confiscation the beretics were forced to furnish the means for their own destruction. Avarice joined hands with fansticism, and between them they supplied motive power for a hondred years of fierce, unintermitting, unrelenting persecution, which in the end accompliabed its main purpose.

HERTEY C. LBA. 